[DOI: 10.24214/jecet.A.8.4.43544.]

Jaurnal of Environmental Science, Computer Science and Engineering \& Technology

An International Peer Review E-3 Journal of Sciences and Technology

Available online at www.jecet.org

Section A: Environmental Science

Research Article

\title{
Physico-chemical, mineralogical, textural and thermal characterizations of natural clay from Yagoua (Far North of Cameroon).
}

\author{
Fabrice Ndiapa*, Joseph Sieliechi, Martin Ngassoum, Yannick Nongni, \\ Marc Cretin and Sophie Cerneaux
}

*Department of Applied Chemistry, National Advanced School of Agro-Industrial Sciences, University of Ngaoundéré, P.O. Box 455, Ngaoundéré, Cameroon

Received: 30 October 20198; Revised: 07 November 2019; Accepted: 12 November 2019

\begin{abstract}
This work focused on the valorization of the natural clay resources from the Yagoua region in the Far North of Cameroon. The physico-chemical, crystallographic, textural and thermodynamic analyzes of this clay were carried out in order to synthesize porous ceramic materials applicable to water treatment. The majority of chemical elements encountered by EDX semi-quantitative analysis were $\mathrm{Si}(16.4 \%)$ and $\mathrm{Al}(8.5 \%)$ which were presented as $\mathrm{SiO}_{2}$ and $\mathrm{A}_{2} \mathrm{O}_{3}$ oxides in the clay material. All the data obtained indicate, with regard to $\mathrm{X}$-ray diffraction, that the clay material consists mainly of kaolinite $\left(\mathrm{Al}_{2} \mathrm{Si}_{2} \mathrm{O}_{5}(\mathrm{OH})_{4}\right)$, quartz $\left(\mathrm{SiO}_{2}\right)$, dolomite $\mathrm{CaMg}\left(\mathrm{CO}_{3}\right)_{2}$ and corundum $\left(\mathrm{Al}_{2} \mathrm{O}_{3}\right)$. Infrared analysis of crude clay revealed the presence of vibration bands related to the $\mathrm{O}-\mathrm{H}, \mathrm{Si}-\mathrm{O}, \mathrm{Al}_{2} \mathrm{OH}, \mathrm{CO}_{3}{ }^{2-}$ bonds characteristic of kaolinite, quartz, and dolomite. The Scanning Electron Microscopy (SEM) of this clay showed the particles were stacked, thus constituting clusters. The nitrogen adsorption-desorption of the clay described a type IV isotherm characteristic of mesoporous solids with a specific surface area of $47.91 \mathrm{~m}^{2} / \mathrm{g}$ and an average pore diameter of $67.91 \AA$, obtained by the BJH (Barrett, Joyner et Halenda) method. Phase transformation analyzes, TGA/DSC (Thermogravimetric analysis/Differential Scanning Calorimetry) indicated the different phase transitions of the material during heating, ranging from dehydration (desorption of the adsorbed hygroscopic water to the surface of the particles), then dehydroxylation (conversion of kaolinite to metakaolinite) and finally recrystallization (transformation of the metakaolinite into a
\end{abstract}


spinel phase (mullite)). This clay had interesting characteristics for the formulation of ceramics materials for different applications.

Keywords: Clay, Mineralogy, X-Ray diffraction, Ceramic materials.

\section{INTRODUCTION}

The mineralogical, chemical, and physico-chemical properties of clays are of particular interest in many applications including water treatment, paint, barrier for pollutants, adsorbent, catalyst, etc. The clay refers to the soft earth containing a set of fine particles whose size is fixed at $2 \mu \mathrm{m}^{1}$. The clay particles result from the physical or mechanical disintegration of the rocks, followed by a chemical transformation. Clay, a natural material that usually contains phyllosilicates (sheets of silicates), is plastic in the wet state and hardens by drying or heating. It can also contain materials that do not induce any plasticity (quartz for example) and / or organic matter: that are associated phases ${ }^{2}$. Thanks to the technical progress of the characterization methods, several studies have shown that the clay materials of montmorillonite, smectite, kaolinite, bentonite, illite, vermiculite or sepiolite have excellent surface properties, thermodynamics, and strong adsorption capacity of heavy metals in effluents. Indeed, this study was carried out to evaluate the potential of clays available locally in the Far North region of Cameroon, specifically in the city of Yagoua. The aim of this work is to perform crystallographic, structural and thermodynamic characterizations of this clay in order to conclude on the possibility of production of ceramic membranes for the improvement of the physico-chemical and microbiological quality of drinking water.

\section{EXPERIMENTAL}

1. Preparation of the clay sample: The clay used in this study is a natural material from the Yagoua

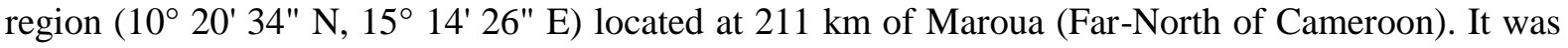
taken more precisely in the valley of the Logone, at the level of the village named Mouka. This site was chosen according to the abundance of the clay deposits which it overflows.

The sample taken at a depth of about $1.5 \mathrm{~m}$ had undergone the following unit operations:

- Crushing and grinding the rocks of the sample into pieces in a mortar, in absence of water;

- $\quad$ Drying in the oven for $24 \mathrm{~h}\left(\right.$ Temperature $\left.=100{ }^{\circ} \mathrm{C}\right)$;

- Sieving the crushed sample (100 - $200 \mu \mathrm{m}$ sieve), just one time.

2. pH analysis, water content, swelling index and loss on Ignition: When a solid is in contact with a solution, the determination of the $\mathrm{pH}$ is necessary to quantify the contribution of the acidity of this compound. To do this, a $10 \%$ solution of $\mathrm{m} / \mathrm{v}$ clay is prepared with distilled water. The mixture is then allowed to stand for $4 \mathrm{~h}$ at $25{ }^{\circ} \mathrm{C}$ to allow the ions to pass into solution. The obtained clay solution is then homogenized using a magnetic stirrer during a few minutes. Reading is done directly on a HANNA pH meter ${ }^{3}$.

The water content can be measured directly by first weighing the sample of material, which determines a mass $\mathrm{m}_{\mathrm{a}}$, and then weighing it after drying in an oven to evaporate the water at $105 \pm$ $5^{\circ} \mathrm{C}$ for 24 hours, to get the weight $\mathrm{m}_{\mathrm{b}}$, necessarily inferior to the preceding one. The moisture content proposed by Chossat ${ }^{4}$ is as follows:

$$
\mathrm{H}(\%)=100 \frac{\left(\mathrm{m}_{\mathrm{a}}-m_{b}\right)}{\mathrm{m}_{\mathrm{b}}}
$$


$\mathbf{m}_{\mathrm{a}}$ : mass of the wet sample $(\mathrm{g})$

$\mathbf{m}_{\mathbf{b}}$ : mass of the dry sample $(\mathrm{g})$

The clay can fix a significant amount of water by absorption inside the lamellar structure, which usually results in swelling. The measurement of the swelling index consists of filling a $100 \mathrm{~mL}$ graduated cylinder with $50 \mathrm{~mL}$ of distilled water and addition of $0.5 \mathrm{~g}$ of clay. After $45 \mathrm{~min}$, a mass of $0.5 \mathrm{~g}$ of clay is again introduced into the initial mixture. After $2 \mathrm{~h}$, the swelling volume is noted. The swelling index is measured by the following formula (Rollet and Bouaziz ${ }^{5}$ ):

$$
\text { Swelling Index }(\%)=\frac{(\text { Swelling volume } \times 50)}{50-\text { Moisture }}
$$

The calcination of a sample at $900{ }^{\circ} \mathrm{C}$ makes possible the determination of the weight loss expressed in \%. The Loss on Ignition (LOI) is interesting to evaluate the quantity of products likely to decompose or to volatilize during the firing cycle. It was measured by placing a quantity of crude clay in a porcelain crucible previously calibrated, at a weight noted $\mathrm{P} 1$. The crucible was then placed in an oven, with a gradual increase of the temperature to $900{ }^{\circ} \mathrm{C}$, for 1 hour. The crucible was then removed and placed in a desiccator to cool down and weighed to give the weight P2. The formula giving the value of the loss on fire is given by the expression(3):

$$
\mathrm{LOI}=\frac{\mathrm{P} 1-\mathrm{P} 2}{\mathrm{P} 1} \times 100
$$

3. Particle size, chemical composition, textural analysis: The granulometric analysis was carried out on a sample prepared as described in section 1 to evidence the particle size distribution of the raw clay. The granulometer used is a Laser Mastersizer 2000 prototype of MALVERN instruments.

The Scanning Electron Microscope (SEM) uses a focused beam of high-energy electrons to generate a variety of signals at the surface of solid specimens. The signals that derive from electron-sample interactions reveal information about the sample including external morphology (texture), elementary chemical composition, and orientation mineralogical assemblages. The elementary chemical composition of the clay powders was achieved using a Hitachi S4500 microscope with an acceleration voltage ranging from $0.5 \mathrm{kV}$ to $30 \mathrm{kV}$. This microscope is also equipped with a Thermofisher EDS detector for chemical analysis of samples from the boron element.

Infrared spectroscopy (IR spectroscopy or Vibrational Spectroscopy) involves the interaction of infrared radiation with matter. The infrared spectra of the clay powder were recorded using a ThermoFisher Nexus FTIR spectrometer in the range $4000-400 \mathrm{~cm}^{-1}$, with a resolution of $4 \mathrm{~cm}^{-1}$, a scan number of 32 and a DTGS Kbr detector. This technique provides the chemical bonds vibrations and thus allows the determination of the chemical composition of the sample.

4. Specific surface area and pore structure: For pore structure analysis, the nitrogen adsorption desorption isotherms should be determined over the widest possible range of relative pressure, while allowing for slow equilibration and other operational problems, particularly at very low pressures. In spite of its artificial nature, the Brunauer - Emmett - Teller (BET) method is still used for the determination of the specific surface area of solid material. The textural characterization of the sieved clay was carried out by the BET method using a Micromeritics Asap 2020 V3.04 H apparatus. This equipment provides information on the specific surface area, the porous volume of the micropores and the mesopores and the average pore size using the t-plot technique.

5. Crystallographic analysis: $X$-ray crystallography is a technique used for determining the atomic and molecular structure of a crystal, in which the crystalline parts cause a beam of incident X-rays to 
diffract into many specific directions following the Bragg conditions. X-ray diffraction analysis thus was carried out on crude clay powder using an X-Pert Pro PAN analytical diffractometer using the $\mathrm{CuK} \alpha$ ray at a wavelength $\lambda=1.541 \AA$ at a voltage of $40 \mathrm{kV}$ and an intensity of $20 \mathrm{~mA}$. The scanning speed being $0.032607 \%$ s.

6. Thermal analysis: Thermal analysis by TGA determines the properties of the studied materials in terms of weight changes occurring upon temperature but also possible crystalline phase transitions from the ATD curve and the DSC analysis. Thermogravimetric (TGA) and Differential Scanning Calorimetry (DSC) analyses of the clay powder were carried out using a simultaneous SDT 2960 apparatus (TA Instruments) in a temperature range from room temperature to $1000{ }^{\circ} \mathrm{C}$ at a speed of 10 ${ }^{\circ} \mathrm{C} / \mathrm{min}$ under air.

\section{RESULTS AND DISCUSSION}

\section{Granulometry, elementary chemical composition and morphology of the studied clay powder}

The granulometric analysis of the clay powder produced using a laser granulometer operating under ultrasounds is represented at figure 1:

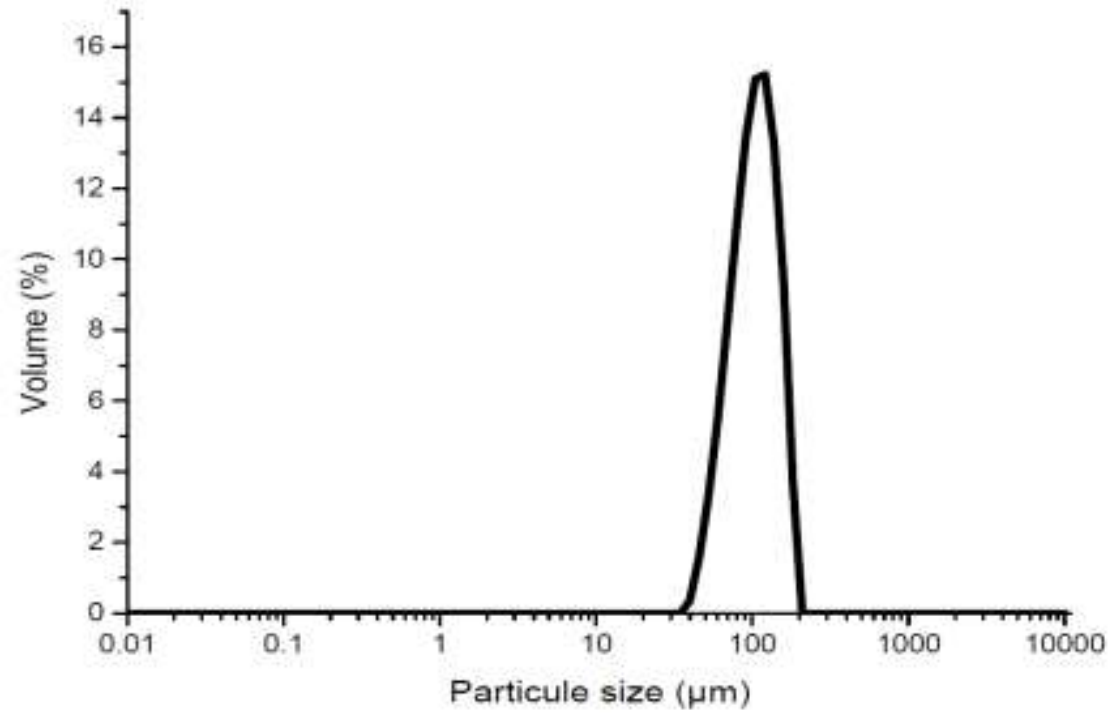

Figure 1: Distribution in size of the clay particles studied

Table 1 presents the distribution of the clay particles in suspension according to their diameter.

Table 1: Granulometric distribution of the clay powder

\begin{tabular}{|c|c|c|c|}
\hline Particles distribution $(\%)$ & 10 & 50 & 90 \\
\hline Particles diameter $(\mu \mathrm{m})$ & 68.1 & 111.4 & 164.7 \\
\hline
\end{tabular}

The results of figure 2 . and table 1 show that $50 \%$ of the studied clay particles have a diameter of $111.4 \mu \mathrm{m}$.

The chemical analysis of the powder of clay carried out using the microscope coupled to a detector EDX Thermofisher was given in table 2 below. 
Table 2: Elementary chemical composition (atomic percentage, $\%$ ) of the studied clay powder

\begin{tabular}{|l|c|c|c|c|c|c|c|c|c|c|c|c|}
\hline $\begin{array}{l}\text { Spectra } \\
\text { description }\end{array}$ & $\mathrm{C}$ & $\mathrm{O}$ & $\mathrm{Na}$ & $\mathrm{Mg}$ & $\mathrm{Al}$ & $\mathrm{Si}$ & $\mathrm{S}$ & $\mathrm{K}$ & $\mathrm{Ca}$ & $\mathrm{Ti}$ & $\mathrm{Fe}$ & Total \\
\hline Spectra 1 & 9.85 & 58.50 & 0.28 & 0.21 & 8.68 & 16.84 & 0.42 & 1.51 & 0.41 & 0.49 & 2.99 & 100 \\
\hline Spectra 2 & 11.01 & 60.53 & 0.4 & 0.21 & 8.49 & 15.53 & 0.21 & 0.98 & 0.25 & 0.37 & 2.36 & 100 \\
\hline Spectra 3 & 10.99 & 58.59 & 0.29 & 0.20 & 8.32 & 16.82 & 0.16 & 0.81 & 0.20 & 0.43 & 3.19 & 100 \\
\hline Mean & 10.62 & 59.20 & 0.24 & 0.21 & 8.50 & 16.40 & 0.21 & 1.07 & 0.29 & 0.43 & 2.85 & - \\
\hline $\begin{array}{l}\text { Standard } \\
\text { deviation }\end{array}$ & 0.67 & 1.15 & 0.08 & 0.01 & 0.18 & 0.75 & 0.04 & 0.38 & 0.11 & 0.06 & 0.43 & - \\
\hline
\end{tabular}

The clay material studied was predominantly characterized by respective mass contents of Silicon and Aluminum of $16.4 \%$ and $8.5 \%$. These elements were present in the clay in the form of $\mathrm{Al}_{2} \mathrm{O}_{3}$ and $\mathrm{SiO}_{2}$ oxides. The silica and alumina present in the clay matrix form the skeletal structure of the ceramic substrates after calcination. The minor chemical elements, $\mathrm{Na}, \mathrm{Mg}, \mathrm{Ca}, \mathrm{K}, \mathrm{Ti}$, form the corresponding oxides $\mathrm{Na}_{2} \mathrm{O}, \mathrm{CaO}, \mathrm{MgO}, \mathrm{K}_{2} \mathrm{O}, \mathrm{TiO}_{2}$, respectively. The iron having a mass content of $2.85 \%$, present in the $\mathrm{Fe}_{2} \mathrm{O}_{3}$ form, was responsible for the red coloration of the ceramic material obtained after sintering at high temperature.

The images obtained by Scanning Electron Microscopy (SEM) of the clay powder studied with different magnifications were shown in figure 2. The morphology was quite regular. These clay particles were in the form of hexagonal plates, elongated and sometimes reduced to pills. In addition, they were stacked one on top of the other (crystals side by side) to form clusters.
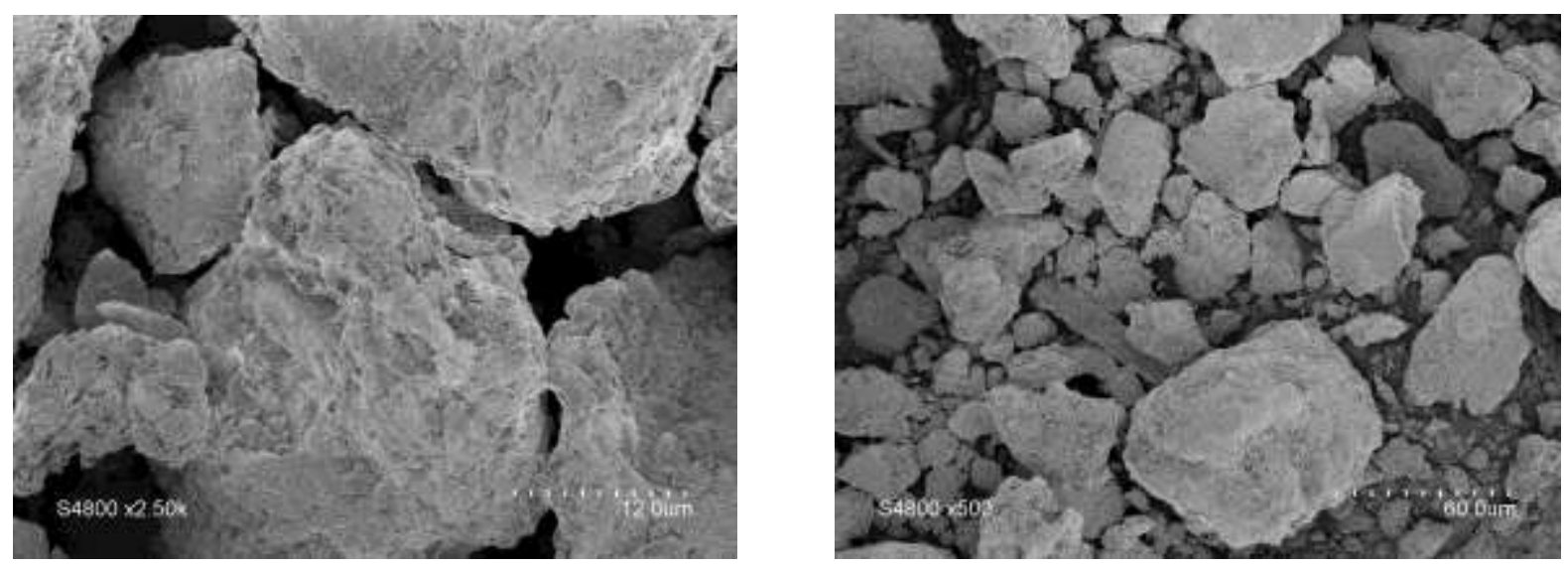

Figure 2: Morphology of the studied clay powder (X2.50 and X500)

2. pH, Moisture content, and loss on ignition (LOI): The physico-chemical parameters related to our sample of clay are summarized in Table 3. The $\mathrm{pH}$ measured has a value of 3.78 , which is due to the acidity of our clay material. This acidity may be due to high concentrations of carbonic acid and soluble salts in the soil solution. The value of the moisture content obtained $(\mathrm{H})$ is $0.94 \%$, indicating the non-hygroscopic nature and thus demonstrating that our sample is considered to be poorly porous. The Loss on Ignition (LOI) at $900{ }^{\circ} \mathrm{C}$ gives a value of the order of $1.08 \%$, which is due to the presence of carbonate and silicate minerals. 
Table 3: Physicochemical parameters of the clay material

\begin{tabular}{|c|c|c|c|c|}
\hline Parameters & $\mathrm{pH}$ & $\mathrm{H}(\%)$ & SI (\%) & Loss on Ignition (\%) \\
\hline Values & 3.78 & 0.94 & 52.49 & 1.08 \\
\hline
\end{tabular}

With: H: Humidity, SI: Swelling Index, LOI: Loss on Ignition.

3. Nitrogen Adsorption/desorption Isotherm (BET) (Brunauer, Emmett and Teller): Figure 3 presented the nitrogen adsorption / desorption isotherm at $77 \mathrm{~K}$ of the clay studied. It showed that the isotherm obtained was of type IV, according to the IUPAC (International Union of Pure and Applied Science) classification, characteristic of the mesoporous solids. $\mathrm{H} 3$ type hysteresis characteristic of porous solids was observed, the size, distribution and shape of the pores of which were not uniform and indicated the likely presence of aggregates of platelet-shaped particles. The specific surface area obtained by the BET method was $47.91 \mathrm{~m}^{2} / \mathrm{g}$.

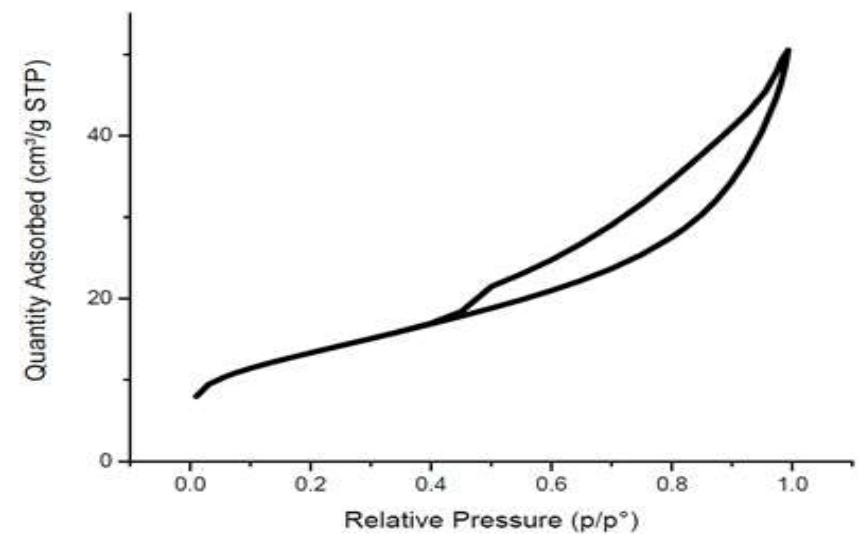

Figure 3: Isotherm of nitrogen absorption/desorption at $77 \mathrm{~K}$ of the Yagoua clay studied

The pore size distribution (PSD) of figure 4 was obtained using the BJH (Barrett, Joyner et Halenda) method on the basis of a discrete analysis of the desorption branch of the isotherm. It showed that the average pore diameter is $67.91 \AA$, indicating a mesoporous structure ${ }^{6}$.

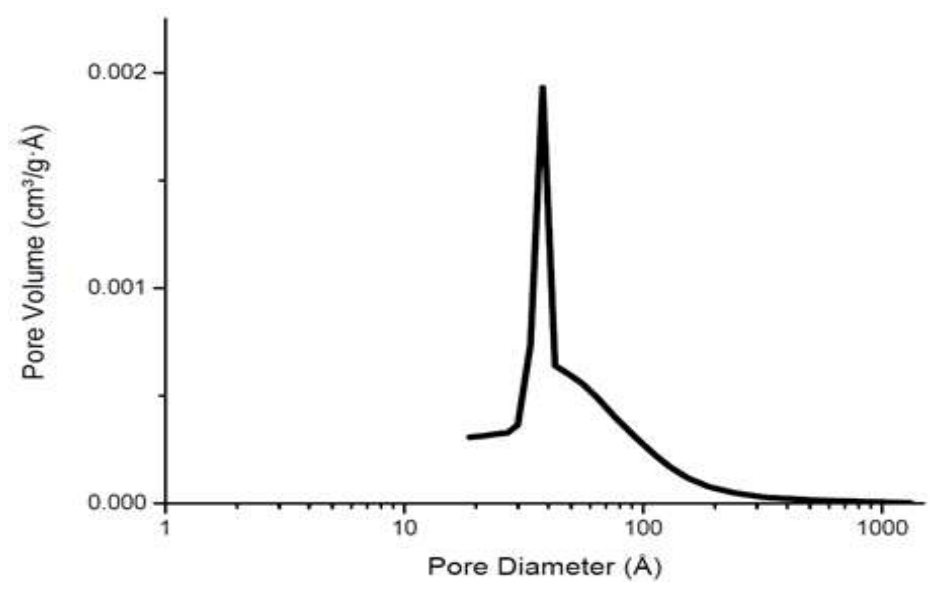

Figure 4: Distribution of the pore diameters of the Yagoua clay studied by the BJH method 
4. Mineralogical phases of a clay studied: The diffractogram obtained from the analysis by X-ray diffraction of the clay powder studied was presented in figure 5.

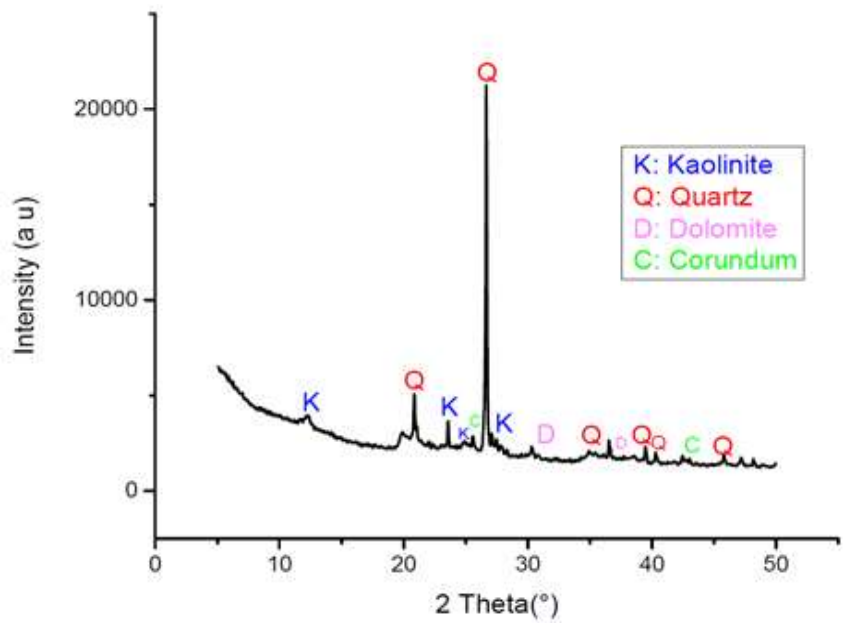

Figure 5: Diffractogram of the Yagoua clay studied $(K=$ kaolinite, $Q=$ Quartz, $D$ $=$ Dolomite, $\mathrm{C}=$ Corundum)

The obtained XRD spectra were matched with the JCPDS (Joint Commitee on Power Diffraction Standards) data base file. The crystalline phases identified in the clay powder were constituted by quartz $\left(\mathrm{SiO}_{2}\right)$ and kaolinite $\left(\mathrm{Al}_{2} \mathrm{Si}_{2} \mathrm{O}_{5}(\mathrm{OH})_{4}\right)$, dolomite $\mathrm{CaMg}\left(\mathrm{CO}_{3}\right)_{2}$ and corundum $\left(\mathrm{Al}_{2} \mathrm{O}_{3}\right)$ which shows the heterogeneity of our clay material.

The characteristic peaks of the presence of kaolinite $\left(\mathrm{Al}_{2} \mathrm{Si}_{2} \mathrm{O}_{5}(\mathrm{OH})_{4}\right)$ in our clay material were detected at angles $2 \theta=12.39^{\circ}(\mathrm{d}=7.13 \AA), 2 \theta=20.15^{\circ}(\mathrm{d}=4.40 \AA), 2 \theta=22.01^{\circ}(\mathrm{d}=4.03 \AA), 2 \theta=$ $23.58^{\circ}(\mathrm{d}=3.76 \AA), 2 \theta=24.93^{\circ}(\mathrm{d}=3.56 \AA), 2 \theta=35.46^{\circ}(\mathrm{d}=2.52 \AA), 2 \theta=36.19^{\circ}(\mathrm{d}=2.47 \AA), 2 \theta$ $=38.38^{\circ}(\mathrm{d}=2.34 \AA), 2 \theta=39.84^{\circ}(\mathrm{d}=2.26 \AA), 2 \theta=27.47^{\circ}(\mathrm{d}=3.24 \AA)$.

The presence of characteristic quartz $\left(\mathrm{SiO}_{2}\right)$ rays was observed at diffraction angles $2 \theta=20.85^{\circ}(\mathrm{d}=$ $4.25 \AA), 2 \theta=26.64^{\circ}(\mathrm{d}=3.34 \AA), 2 \theta=36.56^{\circ}(\mathrm{d}=2.45 \AA), 2 \theta=39.47^{\circ}(\mathrm{d}=2.28 \AA), 2 \theta=40.28^{\circ}(\mathrm{d}$ $=2.23 \AA), 2 \theta=42.42^{\circ}(\mathrm{d}=2.12 \AA), 2 \theta=45.81^{\circ}(\mathrm{d}=1.97 \AA)$.

Dolomite $\left(\mathrm{CaMg}(\mathrm{CO} 3)_{2}\right)$ occurs with low intensity rays at angles $2 \theta=40,970^{\circ}(\mathrm{d}=2.20 \AA), 2 \theta=$ $30.80^{\circ}(\mathrm{d}=2.90 \AA)$.

Corundum (syn, $\mathrm{Al}_{2} \mathrm{O}_{3}$ ) also has peaks of low intensity at angles $2 \theta=25.58^{\circ}(\mathrm{d}=3.47 \AA$ ), $2 \theta=$ $43.37^{\circ}(\mathrm{d}=2.08 \AA), 2 \theta=35.10^{\circ}(\mathrm{d}=2.55 \AA)$.

5. Infrared of clay powder: A Fourier Transform Infrared Spectrophotometer (FTIR) was used to investigate the chemical characteristics of Yagoua clay. Infrared spectrometry on our clay powder showed the different absorption bands represented by figure 6 .

The bands observed on the IR spectrum are as follows:

$3734.9 \mathrm{~cm}^{-1} ; 3693.6 \mathrm{~cm}^{-1} ; 3621.9 \mathrm{~cm}^{-1}$ which correspond to the different valence vibrations of the structural hydroxides of kaolinite ${ }^{7}$;

$3400.05 \mathrm{~cm}^{-1}$ and $1641.6 \mathrm{~cm}^{-1}$ which correspond respectively to the elongation and deformation vibrations of the $\mathrm{OH}$ group of adsorbed water ${ }^{7-10}$; 
$2348.3 \mathrm{~cm}^{-1}$ and $2156.1 \mathrm{~cm}^{-1}$ are the result of the combination of the elongation of the $\mathrm{OH}$ groups with structural deformation vibrations ${ }^{11}$

$994.9 \mathrm{~cm}^{-1}$ and $909.4 \mathrm{~cm}^{-1}$ corresponding to the deformation oscillations $\left(\mathrm{CO}_{3}\right)$ and $\mathrm{Al}_{2} \mathrm{OH}$;

$779.1 \mathrm{~cm}^{-1} ; 681.4 \mathrm{~cm}^{-1}$ which correspond to the deformation vibrations of the Si-O bond of the quartz ${ }^{12,10}$.

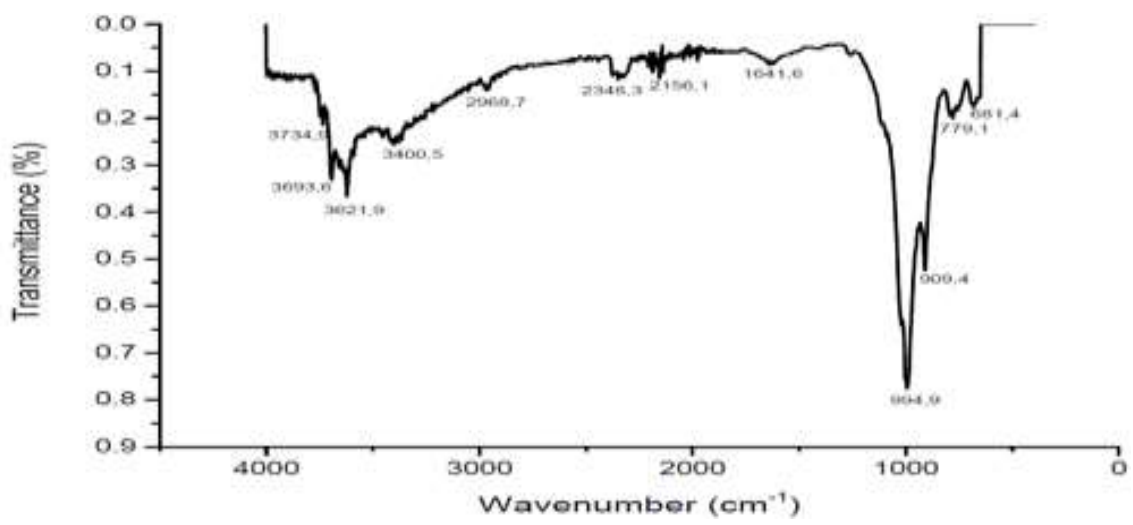

Figure 6: Infrared spectrum (Attenuated Total Reflectance, ATR) of the clay studied

6. Thermogravimetric and Differential scanning calorimetry (TGA-DSC) of a clay studied: The curves for Thermogravimetric (TGA) and Differential Scanning Calorimetry (DSC) analysis of the clay used are shown in figure 7.

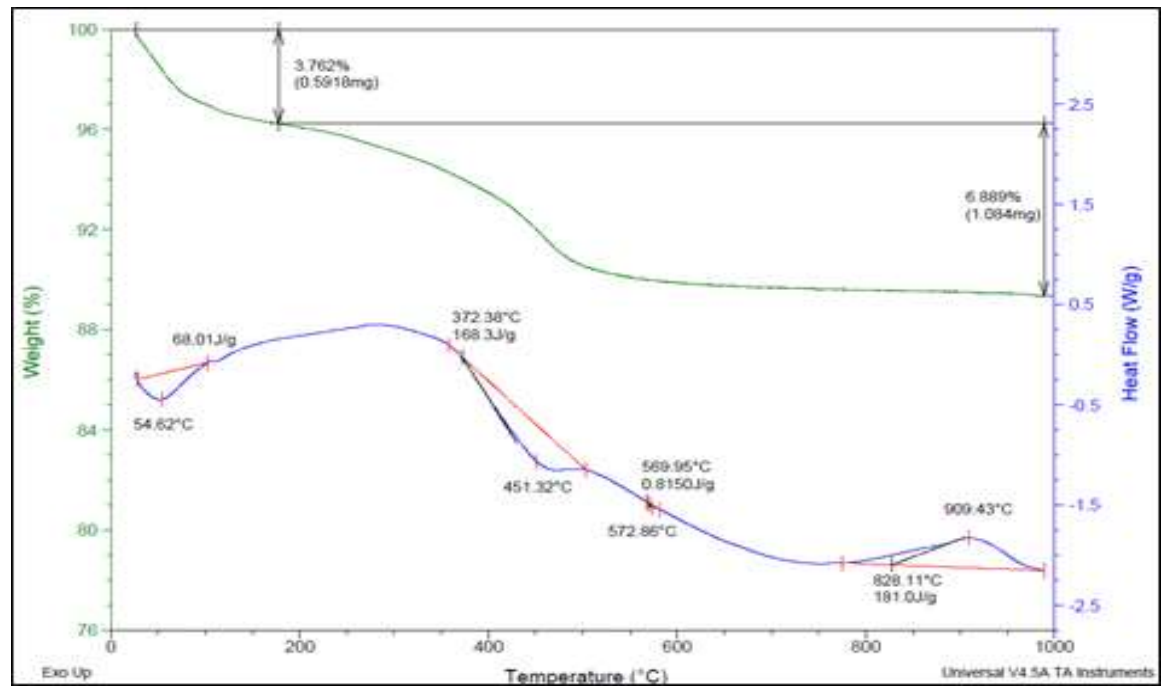

Figure 7: TGA-DSC curves of the crude clay powder

The TGA (Thermogravimetric analysis) curve shows two important mass losses:

- The first loss of $3.76 \%$ extending up to $160{ }^{\circ} \mathrm{C}$ corresponds to the elimination of water adsorbed on the surface and between the lamellar structures of the clay.

- The second loss of $6.89 \%(1.08 \mathrm{mg})$ occurs at about $500{ }^{\circ} \mathrm{C}$ and corresponds to the decomposition of hydroxyl groups and carbonates ${ }^{13}$.

The DSC (Differential Scanning Calorimetry) curve shows three important peaks: 
- A first endothermic peak at $54.62{ }^{\circ} \mathrm{C}$ is due to the departure of the surface water (dehydration);

- A second endothermic peak, large and asymmetric at $451.32{ }^{\circ} \mathrm{C}$, corresponds to decomposition (dehydroxylation) of mixed carbonates of magnesium and calcium (dolomite) $)^{14}$. During this step, the transformation of kaolinite into metakaolinite occurs ${ }^{15-18}$.

$2 \mathrm{SiO}_{2} \cdot \mathrm{Al}_{2} \mathrm{O}_{3} \cdot 2 \mathrm{H}_{2} \mathrm{O}$. (Kaolinite) $\longrightarrow 2 \mathrm{SiO}_{2} \cdot \mathrm{Al}_{2} \mathrm{O}_{3}$ (metakaolinite) $+2 \mathrm{H}_{2} \mathrm{O}$

- The exothermic peak at $909.43{ }^{\circ} \mathrm{C}$ with no weight loss corresponds to the structural reorganization of the minerals with the formation of a spinel phase from metakaolinite (corresponding the mullite formation) $)^{19,16-18}$. The most common descriptions are:

$$
\begin{aligned}
& 2 \mathrm{SiO}_{2} \cdot \mathrm{Al}_{2} \mathrm{O}_{3} \text { (metakaolinite) } \longrightarrow \mathrm{SiAl}_{2} \mathrm{O}_{4} \text { (spinel) }+\mathrm{SiO}_{2} \text { (amorphous) } \\
& 2 \mathrm{SiO}_{2} \cdot \mathrm{Al}_{2} \mathrm{O}_{3} \text { (metakaolinite) } \longrightarrow \mathrm{Al}_{2} \mathrm{O}_{3}\left(\gamma \text {-alumina) }+2 \mathrm{SiO}_{2}\right. \text { (amorphous) }
\end{aligned}
$$

\section{CONCLUSION}

The aim of this work was to identify the potential for the valorization of clay resources, abundant in the Yagoua region. The elementary chemical composition of the clay powder studied reveals the presence of the major elements $\mathrm{Al}, \mathrm{Si}$ and $\mathrm{Fe}$, and the minor species, $\mathrm{Na}, \mathrm{Ca}, \mathrm{Mg}, \mathrm{Ti}, \mathrm{S}, \mathrm{K}$. The morphology of the clay studied showed stacked particles in the form of aggregates. The results of the various characterization techniques made on the clay material also showed that it was a mixture of kaolinite $\left(\mathrm{Al}_{2} \mathrm{Si}_{2} \mathrm{O}_{5}(\mathrm{OH})_{4}\right)$, silica in the form of quartz $\left(\mathrm{SiO}_{2}\right)$, dolomite $\left(\mathrm{CaMg}\left(\mathrm{CO}_{3}\right)_{2}\right)$ and corundum $\left(\mathrm{Al}_{2} \mathrm{O}_{3}\right)$. The presence of the mullite phase $\left(\mathrm{SiAl}_{2} \mathrm{O}_{4}\right)$ due to the transformation of metakaolinite $\left(2 \mathrm{SiO}_{2} \cdot \mathrm{Al}_{2} \mathrm{O}_{3}\right)$ was also observed on the results of the TGA-DSC analysis. The infrared absorption bands complemented the X-ray diffraction results and allowed the detection of $\mathrm{H}-\mathrm{OH}$ vibrations, $\mathrm{Si}$ $\mathrm{O}-\mathrm{Si}$ bonds and $\mathrm{Al}_{2}-\mathrm{OH}$ bonds. This material also had a surface area $\left(47.91 \mathrm{~m}^{2} / \mathrm{g}\right)$ which is advantageous for use as an adsorbent material or in the formulation of ceramic supports acting as filter for water treatment.

\section{ACKNOWLEDGEMENT}

This work was supported by the "Agence Universitaire de la Francophonie" (AUF) (Bureau Afrique Centrale et Grands Lacs" (BACGL). The authors also thank the following institutions: "Institut Européen des Membranes" (IEM, Montpellier (France)), Ecole Nationale Supérieure des Sciences Agro-Industrielles" (ENSAI, Ngaoundéré (Cameroon)), "Ecole Nationale Supérieure de Chimie de Montpellier" (ENSCM, Montpellier (France)) for the analyses carried out.

\section{REFERENCES}

1. S. Caillère, S. Hénin, M. Rautureau. "Minéralogie des argiles : Classification et nomenclature (Tome 2)", [J]. Ed. Masson, Paris. 1982. 9, 107 et 114.

2. AIPEA (Association Internationale Pour l'Etude des Argiles), Newsletter n³2, February 1996.

3. N.C. Amin, Y.Y.J. Andji, M. Ake, S.F. Yolou, A. Toure Abba, J. Kra Gabrielle. [J]. J. Sci. Pharm. Biol. 2009. 10, 21. 
4. J.C. Chossat, La mesure de la conductivité hydraulique dans les sols - Choix des méthodes. [J]. Lavoisier, USA. 2005, 720 pp.

5. P. Rollet, R. Bouaziz, L'analyse thermique - les changements de phase. [J]. ED. GautierVillard, Tome 1, Paris. 1972.

6. B. Khoumeri, Thèse de Doctorat, Université des sciences et techniques du Languedoc. 1990.

7. V. C. Farmer, The infrared spectra of minerals. [J]. Mineralogical Society of Great Britain and Ireland. Vol 4. 1974.

8. H. Van Olphen, J. J. Fripiar, Data handbook for clay materials and other non-metallic minerals. [J]. Soil Science. 1981, 62, 131.

9. L.J. Bellamy, The Infrared spectra of complex molecules. [J]. Vol. 1,3. Aufage, Chapman and Hall Ltd, London, 433 Seiten, 32 Abb., 22 Tabellen, Preis : 8. 1975.

10. J.E. Boulingui, C. Nkoumbou, D. Njoya, F. Thomas, J. Yvon, Characterization of clays from mezafe and mengono (ne-libreville, gabon) for potential uses in fired products. [J]. Applied Clay Science. 2015, 115: 132-144.

11. S. Petit, J. Madejova, A. Decareau, F. Martin, "Characterization of octahedral substitutions in kaolinites using near infrared spectroscopy." [J]. Clays and Clay Minerals. 1999, 47, (1): 103108.

12. HW. Van der Marel, H. Beutelspacher, Atlas of infrared spectroscopy of clay minerals and their admixtures. [J]. Elsevier Publishing Company. 1976.

13. O. Qabaqous, N. Tijani, M. Naciri Bennani1, A. El Krouk, Elaboration et caractérisation des supports plans à base d'argile (Rhassoul) pour membranes minérales. [J]. Mater. Environ. Sci. 2014. 5 (S1) : 2244-2249.

14. Abdelaziz Benhammou, Thèse de Doctorat, Université Cadi Ayyad, Faculté des sciences Semlalia Marrakech, Maroc. 2005.

15. B. K. Benazzouz and A. Zaoui, "Thermal behaviour and superheating temperature of Kaolinite from molecular dynamics," Applied Clay Science. [J]. 2012. 58 : 44-51.

16. B. R. Ilić, A. A. Mitrović, and L. R. Miličić, "Thermal treatment of kaolin clay to obtain metakaolin," [J]. Hem. Ind. 2010. 64 : 351-356.

17. P. Ptáček, D. Kubátová, J. Havlica, J. Brandštetr, F. Šoukal, and T. Opravil, "The nonisothermal kinetic analysis of the thermal decomposition of kaolinite by thermogravimetric analysis." [J]. Powder technology. 2010. 204 : 222-227.

18. K. Traoré, P. Blanchart, J.-P. Jernot, and M. Gomin, "Caractérisation physicochimique et mécanique de matériaux céramiques obtenus à partir d'une argile kaolinitique du Burkina Faso," [J]. C. R. Chimie. 2007. 10 : 511-519.

19. F. Gridi-bennadji, "Matériaux de mullite à microstructure organisée composés d'assemblages muscovite - kaolinite," France: Université de Limoges. 2007.

\section{Corresponding author: Fabrice Ndiapa}

Department of Applied Chemistry, National Advanced School of Agro-Industrial Sciences, University of Ngaoundéré, P.O. Box 455, Ngaoundéré, Cameroon 